Tropical Agricultural Pesearch \& Extension 20 (1 \& 2): 2017

\title{
THE RELATIONSHIP BETWEEN RAINFALL CHARACTERISTICS AND PROSO MILLET (Panicum miliaceum L.) CULTIVATION IN LOW COUNTRY DRY ZONE, SRI LANKA
}

\author{
EM Wimalasiri ${ }^{1 *}$, MJ Ashfold ${ }^{2}, \mathrm{~S}$ Walker ${ }^{1,3}$, SP Nissanka ${ }^{4}$ and AS Karunaratne ${ }^{5}$ \\ ${ }^{1}$ School of Biosciences, Faculty of Science, University of Nottingham Malaysia Campus, Jalan Broga, 43500 Semenyih, \\ Selangor, Malaysia \\ ${ }^{2}$ School of Environmental and Geographical Sciences, Faculty of Science, University of Nottingham Malaysia Campus, \\ Jalan Broga, 43500 Semenyih, Selangor, Malaysia \\ ${ }^{3}$ Department of Soil, Crop and Climate Sciences, University of Free State, PO Box 339, Bloemfontein 9300, South Africa \\ ${ }^{4}$ Department of Crop Science, Faculty of Agriculture, University of Peradeniya, Sri Lanka \\ ${ }^{5}$ Faculty of Agricultural Sciences, Sabaragamuwa University of Sri Lanka, PO Box 02, Belihuloya 70140, Sri Lanka
}

\begin{abstract}
Proso millet (Panicum miliaceum L.) is a drought tolerant minor millet found in rainfed low input agricultural systems in Sri Lanka. This paper presents an analysis of characteristics of rainfall, of the onset, retreat and length of the 'Yala' growing season (March-September) and the relationship between rainfall and crop husbandry strategies in a Proso millet growing area. Daily rainfall data (1983-2015) obtained from Udawalawa, Sewanagala, Pelwatta, Thanamalwila and Kuda Oya meteorological stations were analysed along with information gathered from a survey of farmers. Among these 5 stations significant $(p<0.05)$ differences were found in retreat date, the length of the season and rainfall amount during the season. It was observed that onset date can be used to predict the season length with high accuracy $(r=-0.7335$, significant at $p<0.05)$. The selection of crops and the timing of crop management practices in the Proso millet growing area coincided with the distribution of rainfall. However, the yields reported by farmers (mean $1.18 \mathrm{t} \mathrm{ha}^{-1}$ ) are far below the expected potential $\left(4 \mathrm{t} \mathrm{ha}^{-1}\right)$. Soil moisture conservation and water management strategies could be critical to reduce the risk of water-related damage in the susceptible flowering stage.
\end{abstract}

Key words: daily rainfall, onset, Proso millet, rainfed, Yala

\section{INTRODUCTION}

Proso millet (Panicum miliaceum L.), belonging to family Poaceae, is a crop with low water requirement (Baltensperger, 2002; Changmei and Dorothy, 2014) and has been highlighted as a crop that is particularly useful in a climate where rainfall might be less reliable (Swaminaidu et al., 2015). It survives and gives yield under conditions with annual rainfall as little as $300 \mathrm{~mm}$ (Changmei and Dorothy, 2014). Excellent adaptability of this hardy crop to adverse effects of agro-climatic variations play an important role in agriculture in marginal areas, such as is commonly practised in hilly and semi-arid India (Ravi et al., 2010). It is important that these hardy crops receive research attention because resilient agriculture is a good strategy to overcome the increased

\footnotetext{
*Corresponding author: emadushan@gmail.com
}

risk of droughts and monsoon-related inter annual rainfall variability in the Asian region (IPCC, 2014).

Proso millet is the principal crop in Low Country Dry Zone (LCDZ) in Sri Lanka during minor cultivation season (Yala). It is found in one of the primitive agricultural systems known as Chena, grown as a rainfed crop where minimum tillage conditions are used during the drier part of the year with low inputs (under shifting cultivation). As a result of the monsoons rainfall in Sri Lanka typically follows a distinctly bimodal pattern, leading to two cropping seasons. Especially in the Dry Zone (DZ), the principal or the major cultivation season (Maha - wet season) starts with Second Inter-Monsoon (SIM- October to November) and ends with the cessation of North 
East Monsoon (NEM- December to February). The subsidiary cultivation season or the minor growing season (Yala - dry season) constitutes of six months that includes First InterMonsoon (FIM-March to May) and South West Monsoon (SWM-June to September) periods (Suppiah, 1996; De Silva et al., 2007). Different crops and crop combinations are cultivated in the country under matched cropclimate scenarios.

Gunarathna et al., (2004) claimed that in line with the changes of rainfall pattern in Hambanthota district in the LCDZ with respect to the magnitude, the risk of dry spells and onset, the cropping calendar also changed. Further, changes in rainfall pattern create water shortage periods during cropping seasons that badly affects crop yield. This example illustrates the importance of adjusting the cropping calendar to suit the current rainfall pattern in the DZ of Sri Lanka (Gunarathna et al., 2004).

Knowledge of the probable dates of onset and retreat of the rainy season and the duration of dry spells is very useful for farmers in planning various agronomic practices such as land preparation, seed/plant arrangement, sowing, labour and machinery, harvesting, threshing and drying (Omotosho et al., 2000; Mavi and Tupper, 2004). Each crop has its own critical periods during its growing season. Farmers can adjust sowing periods in a way that moisture sensitive stages do not fall during dry spells based on the knowledge on the frequency of occurrence of wet and dry spells during growing period (Gunarathna et al., 2004; Mavi and Tupper, 2004). Sri Lankan farmers use several empirical techniques, such as the sighting of the migrant Grey Wagtail bird to anticipate the rain (Zubair, 2002). Identification of sowing and onset/retreat days and existing strategies on crop selection and crop management will be helpful in agricultural decision making in the future under a changing climate (Gunarathna et al., 2004).

A knowledge gap exists for the Proso Millet grown in Sri Lanka by smallholders in mixed farming systems especially on the preferred geographic locations, climate resilience, and how to improve varieties, yield and quality. Therefore, exploitation of existing traditional knowledge and its potential usage to promote Proso millet cultivation and productivity further will directly contribute to the national development goals of enhancing food and nutrition security. Very limited research attention has been devoted to assessing the links between agro-climatic characteristics and cultivation of Proso millet in Sri Lanka. Therefore, this paper explores the present situation of Proso millet cultivation and the characteristics of rainfall and growing season and farmer's crop husbandry strategies on Proso millet farming systems in Low Country Dry Zone in Sri Lanka.

\section{MATERIALS AND METHOD Site description}

Proso millet growing region that belongs to LCDZ region 1a $\left(\mathrm{DL}_{1 \mathrm{a}}\right.$ - a region in the south of Sri Lanka characterised by $1100-1750 \mathrm{~mm} /$ year rainfall) and $\mathrm{LCDZ}$ region $1 \mathrm{~b}\left(\mathrm{DL}_{1 \mathrm{~b}}\right.$ characterised by $900-1750 \mathrm{~mm} /$ year rainfall) was selected for the study (Figure 1A).

\section{On-farm field survey}

A field survey was conducted during MarchJune, 2015 in Proso millet growing regions of Bodagama $\left(6.41-6.44^{\circ} \mathrm{N}, 81.08-81.12^{\circ} \mathrm{E}\right)$, Sri Lanka (Figure 1B). The area was selected because farming Proso millet is a key feature of most people's livelihood in the area. Fifty farmers were selected using the simple random sampling technique. Researcher administered pre-tested questionnaires were used to collect data on sowing and harvesting dates, crop selection and management practices.

Proso millet plants were harvested from 41 farm fields that covered by the survey, at harvesting stage during $23^{\text {rd }}$ May to $4^{\text {th }}$ June 2015 , and the yield analysis was performed. One square meter quadrant was used at three randomly selected locations in the farmers' fields. 

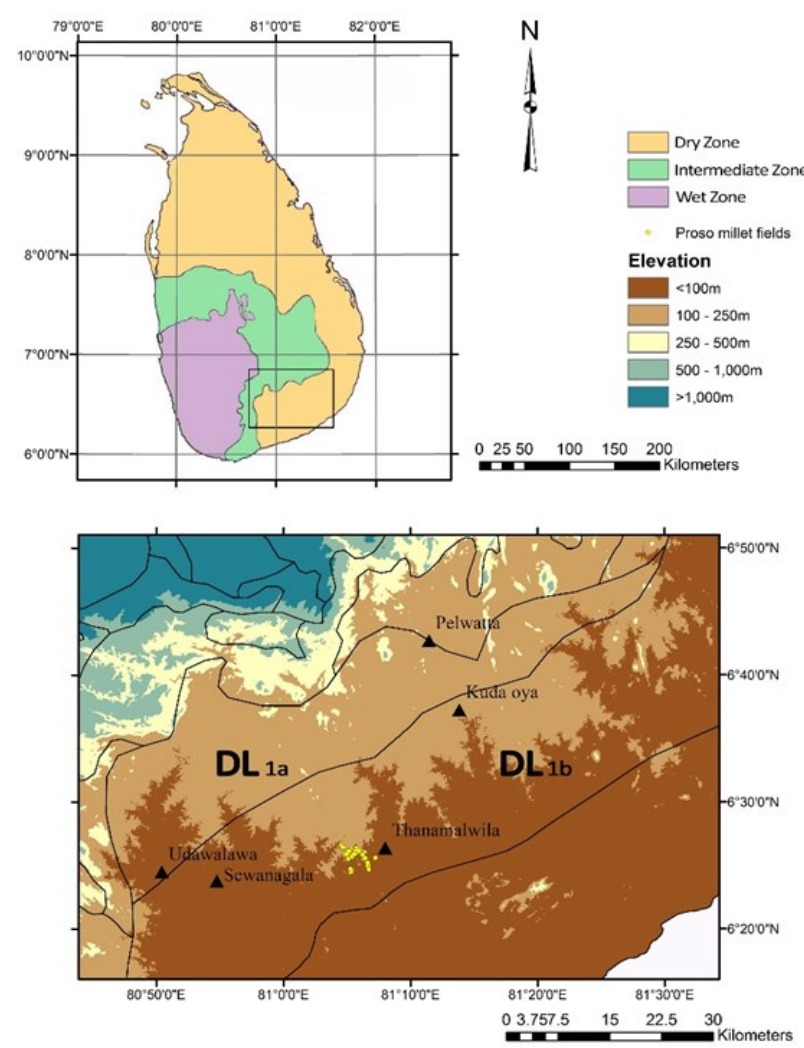

Figure 1A: Major climatic regions and location of the Proso millet growing area (black square) within Sri Lanka and (B) the distribution of meteorological stations (black triangles) and farmer's fields (yellow circles) used in the study. The $\mathrm{DL}_{1 \mathrm{a}}$ and $D_{1 b}$ AEZs are also marked. Black lines are the boundaries between AEZs.

\section{Climate data}

Station data

Historical daily rainfall data were collected from five meteorological stations located in the Proso millet growing region (Figure 1B). Data from Pelwatta $\left(6.72^{\circ} \mathrm{N}, 81.20^{\circ} \mathrm{E}\right.$, covering 1983-2015) and Sewanagala $\left(6.40^{\circ} \mathrm{N}\right.$, $\left.80.91^{\circ} \mathrm{E}, 1986-2015\right)$ were collected from Lanka Sugar Company Ltd., Udawalawa $\left(6.41^{\circ} \mathrm{N}, 80.84^{\circ} \mathrm{E}\right.$, for $\left.1993-2015\right)$ from Sugarcane Research Institute Sri Lanka and Thanamalwila $\left(6.44^{\circ} \mathrm{N}, 81.13^{\circ} \mathrm{E}, 1989-2015\right)$ and Kuda Oya $\left(6.62^{\circ} \mathrm{N}, 81.23^{\circ} \mathrm{E}, 1989-2015\right)$ from stations governed by the Department of Irrigation Sri Lanka (Table 1).

\section{Reanalyses data}

Rainfall in DZ Sri Lanka is erratic (Sonnadara 2015) and localised. For this reason, to obtain data during the study period for the area where the farmer survey was conducted, we used the NASA Prediction of Worldwide Energy Resource (Zhang et al., 2007) dataset (https://power.larc.nasa.gov/) derived from the Goddard Earth Observing System assimilation model and available on a 1-degree grid.

\section{Definitions for wet day, onset, retreat and length of growing season}

Growing season starts on the first day when the rainfall amount equals or exceeds a defined threshold value (Aviad et al., 2004). Following Stern et al., (2003) we defined a wet day as a day with more than $0.85 \mathrm{~mm}$ rainfall. Therefore, a day with less than 0.85 $\mathrm{mm}$ of precipitation was considered as a dry day.

A number of definitions of the onset and retreat of the growing season exist in the literature depending on the geographical location and the timescale used (Punyawardena 2002; Gunarathna et al., 2004; Sonnadara 2015). A criterion for onset and retreat that is favourable for Proso millet growing region in Sri

Table 1: Geographical distribution and rainfall dataset of five meteorological stations used in the study

\begin{tabular}{lccccc}
\hline Station & $\begin{array}{c}\text { Agro } \\
\text { ecological zone }\end{array}$ & Latitude $\left({ }^{\circ} \mathrm{N}\right)$ & Longitude $\left({ }^{\circ} \mathrm{E}\right)$ & Data period & Missing data \% \\
\hline Pelwatta & $\mathrm{DL}_{1 \mathrm{a}}$ & 6.72 & 81.20 & Jan 1983-Dec 2015 & - \\
Udawalawa & $\mathrm{DL}_{1 \mathrm{a}}$ & 6.41 & 80.84 & Jan 1993-Jul 2015 & - \\
Sewanagala & $\mathrm{DL}_{1 \mathrm{~b}}$ & 6.40 & 80.91 & Jul 1986-Jul 2015 & 2.57 \\
Thanamalwila & $\mathrm{DL}_{1 \mathrm{~b}}$ & 6.44 & 81.13 & Oct 1989-Nov 2015 & 3.84 \\
Kuda Oya & $\mathrm{DL}_{1 \mathrm{~b}}$ & 6.62 & 81.23 & Oct 1989-Nov 2015 & 1.90 \\
\hline
\end{tabular}


Lanka was selected. Rainfall in the DZ of Sri Lanka is irregular, therefore, it is important to evaluate rainfall for a few consecutive weeks to avoid false start (Punyawardena 2002; Sonnadara 2015). Marteau et al., (2011) reported that dry spells lasting at least 7 days after a 2day wet spell caused failures of Pearl millet, a similar crop to Proso millet, sown in Southwest Niger. False start of a season was avoided by not allowing a dry spell of more than 10 days after the start of the growing season (Mupangwa et al., 2011).

Therefore, the onset of the season was defined as the first occasion with more than $20 \mathrm{~mm}$ rainfall in a 1 or 2 days period after $1^{\text {st }}$ March with no dry spell of 10 days or more within the following 30 days period. Any onset after $1^{\text {st }}$ May was considered as a very late onset event. The retreat of the season was defined as the first occurrence of a dry spell of three consecutive weeks with less than $20 \mathrm{~mm}$ of rainfall after $1^{\text {st }}$ May, as adopted by Punyawadena (2002) for the DZ of Sri Lanka. The period between onset and retreat was considered as the length of the growing season.

\section{Long-term trends of onset and retreat days}

Nonparametric Mann-Kendall trend analysis (Mann, 1945; Kendall, 1975) was performed to detect the long-term variations in onset and retreat dates. A positive value of the MannKendall statistics indicates increasing trend, i.e., value increase with time and a negative value indicates decreasing trend, i.e., value decrease with time. Retreat dates for very late onset were omitted in the analysis because the Yala season was considered to have failed in those years and onset dates would belong to Maha (major) season.

\section{Dry spell analysis}

Daily rainfall data were used to evaluate the trends in dry spells in Proso millet growing regions in Sri Lanka. For the precise estimation of the direct method of climate data analysis, at least 30 years of climate data are necessary (Stern et al., 2003), therefore an alter- native approach was used. The daily rainfall data were fitted according to zero-order Markov chain model. It was assumed that the amount of daily rainfall follows an exponential distribution (Stern et al., 2003). Dry spells that last more than 7 days are linked with resowing of Pearl millet in Niger due to death of germinated plants (Marteau et al., 2011) and can adversely affect the final yield. Therefore, the probability of 7-day dry spells over the period of 30 days centred on a particular day was plotted by Markov chain model for the Proso millet growing season.

\section{Data analysis}

Dry spells were analysed using Instat Statistical Programme (Version 3.036, Stern et al., 2003). The relationship between onset and length of the season and, onset and seasonal rainfall at each meteorological station were determined using regression analysis.

\section{RESULTS AND DISCUSSION \\ Rainfall distribution and crop cultivation pattern in the region}

Distribution of rainfall in Proso millet growing area in Sri Lanka showed a bimodal variation with two peak rainy periods centred on April and November (Figure 2A). The first peak belongs to Yala season and the second to Maha season. Farmers cultivate Proso millet during the initial phase of Yala season where they get the highest rainfall amount.

It was observed that distribution of rainfall determines the selection of crops and management practices in the area (Figure 2B). The survey data revealed that Proso millet farmers start to clear lands from mid January - February and finish by mid March. They clear scrub jungles/fallow vegetation and burn it to begin cultivation. They start Proso millet cultivation generally after $15^{\text {th }}$ March, with the commencement of rain from FIM and harvest 6070 days after sowing, i.e. in late May - early June period. Since June - July is a drier period in the region (Figure 2A), farmers harvest, thresh and sundry Proso millet seeds without 
being affected by rain. Farmers in the area are not involved in agricultural practices during August because it is dry and very hot during that part of the year. They start land preparation for Other Field Crops (OFC) such as finger millet (Eleusine coracana), foxtail millet (Setaria italic), sesame (Sesamum indicum), mungbean (Vigna radiata) and groundnut (Arachis hypogaea) during September, the last month in Yala season. Some farmers cultivate these crops in their backyards while others in cleared lands that have been used for Proso millet cultivation. The lifespan of these crops are longer than Proso millet and they require more water (Department of Agriculture Sri Lanka- DOASL http:// www.agridept.gov.lk/). High rainfall from SIM and NEM during Maha season fulfils the water requirement of these crops. Most of the farmers also do paddy cultivation during that period because they receive enough rainfall and the OFC do not require much attention.
Both rice and OFC are harvested in midDecember - January. Again, Proso millet farmers start land preparation in following year for Yala season in a different location or same field and this cycle continues. It was clearly observed that the pattern of agriculture in Proso millet growing region is directly linked to the distribution of rainfall (Figure 2B).

\section{Plant density and the yield}

Observation of farmer fields in Bodagama, Sri Lanka during Yala season 2015 gave plant density varying from 61 to 601 plants $\mathrm{m}^{-2}$. The mean (with standard deviation-SD) of $217 \pm 94$ plants $\mathrm{m}^{-2}$ is far above the recommended plant density $\left(33-44 \mathrm{~m}^{-2}\right)$ by DOASL which is a seed rate of 5-6 $\mathrm{kg} \mathrm{ha}^{-1}$ while farmers in this area broadcast about $10-25 \mathrm{~kg} \mathrm{ha}^{-1}$ seeds making highly uneven fields in terms of spatial plant distribution. It seems that to maintain a very high plant density is the only

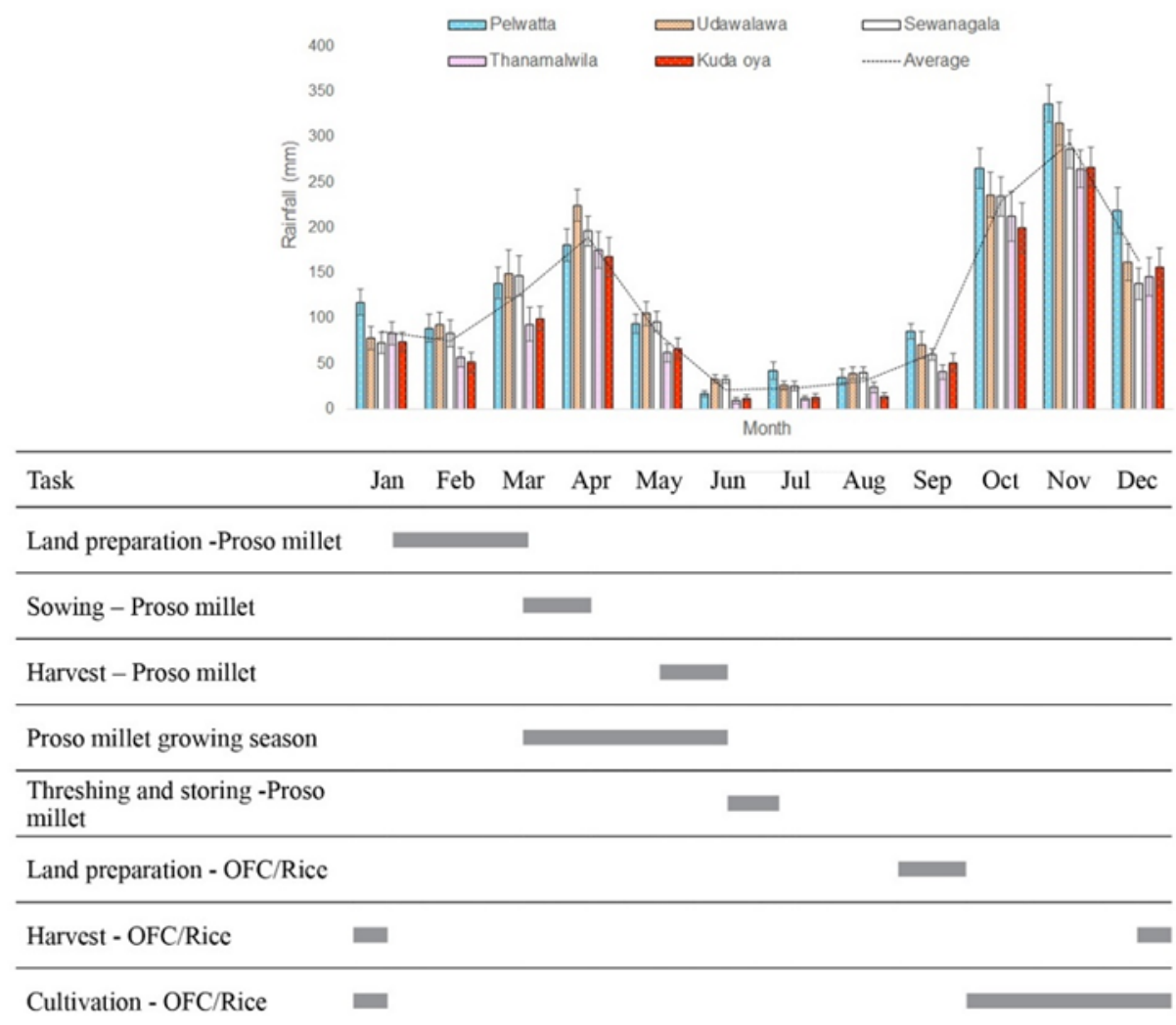

Figure 2: (A) Distribution of mean monthly rainfall during the 1983-2015 period and (B) farming activities during the year in Proso millet growing regions of Sri Lanka. The standard error of mean (SEM) is used in error bars. 
option adopted by Proso millet farmers in the area to protect the crop against the damage to occurred due to rainfall and animals (birds and elephants).

The yield of Proso millet samples collected from farmers' fields varied from $0.470 \mathrm{t} \mathrm{ha}^{-1}$ to $1.956 \mathrm{t} \mathrm{ha}^{-1}$ with the mean of $1.180 \mathrm{t} \mathrm{ha}^{-1}$. Mean yield was lower than the potential yield of $4 \mathrm{t} \mathrm{ha}^{-1}$ (DOASL). Proso millet yield was lower than $1.0 \mathrm{t} \mathrm{ha}^{-1}$ in $31.7 \%$ of farmers' fields indicating widespread low yields of Proso millet in Bodagama, Sri Lanka for 2015 growing season.

\section{Rainfall amount}

The mean annual rainfall of the Proso millet growing region was $1399 \pm 194 \mathrm{~mm}$ during the study period while for stations in $\mathrm{DL}_{\mathrm{la}}$ and $\mathrm{DL}_{1 \mathrm{~b}}$ AEZs it was $1578 \pm 63 \mathrm{~mm}$ and $1280 \pm 140 \mathrm{~mm}$ respectively. The lower limits of mean annual rainfall according to the definitions of $\mathrm{DL}_{1 \mathrm{a}}$ and $\mathrm{DL}_{1 \mathrm{~b}}$ AEZs are $1100 \mathrm{~mm}$ and $900 \mathrm{~mm}$ respectively, and the upper limit of DZ is $1750 \mathrm{~mm}$ (Punyawardena, 2008). The annual rainfall during the 1983-2015 period was below the upper limit ( $p>0.05$ in one sample t-test and $\mathrm{z}$-test), confirming that all the stations studied belong to the DZ (Table 2).

The mean amount of rainfall during the Proso millet growing season $(361 \pm 62 \mathrm{~mm})$ is higher

Table 2: Mean annual and Proso millet growing seasonal $\left(15^{\text {th }}\right.$ March-15 ${ }^{\text {th }}$ June) rainfall of the Proso millet growing regions during 1983-2015 period with standard deviation.

\begin{tabular}{lcc}
\hline Station & $\begin{array}{c}\text { Total annual } \\
\text { rainfall }(\mathrm{mm})\end{array}$ & $\begin{array}{c}\text { Proso millet } \\
\text { growing } \\
\text { seasonal } \\
\text { rainfall }(\mathrm{mm})\end{array}$ \\
\hline Pelwatta & $1623 \pm 314$ & $374 \pm 140$ \\
Udawalawa & $1534 \pm 246$ & $437 \pm 85$ \\
Sewanagala & $1439 \pm 295$ & $397 \pm 96$ \\
Thanamalwila & $1226 \pm 370$ & $302 \pm 122$ \\
Kuda Oya & $1175 \pm 328$ & $293 \pm 123$ \\
\hline
\end{tabular}

than the lower limit $(300 \mathrm{~mm})$ where Proso millet gives a satisfactory yield, according to the literature (Changmei and Dorothy 2014). Out of all, a mean of $36.4 \%$ Proso millet growing seasons in the region received less than the lower limit while the highest incidences were from the driest parts, as Kuda Oya $75 \%$ and Thanamalwila $54.2 \%$, suggesting rainfall amount is a limiting factor for Proso millet cultivation in these areas. The study area received more rainfall than the mean annual rainfall during the last 7 years (2008-2014) prior to the on-farm field survey (Figure 3). These recent experiences are the evidence that farming community was able to recall easily and use in agricultural decision making.

The relationship between annual rainfall and the percentage of rainfall during Proso millet growing season gave a poor relationship $\left(\mathrm{R}^{2}=\right.$ 0.0147) across the region. Therefore, the amount of rainfall received during Proso millet growing season does not have a clear impact on the total annual rainfall in the area.

\section{Onset, retreat and length of the growing season}

No significant differences $(\mathrm{p}>0.05)$ were observed in the time of the onset of the growing season between meteorological stations whereas significant differences $(\mathrm{p}<0.05)$ were observed in retreat date of the season (Table 3). The mean onset and retreat across the region were $24^{\text {th }}$ March (belongs to $12^{\text {th }}$ week starting from January) and $15^{\text {th }}$ May $\left(20^{\text {th }}\right.$ week) respectively. In general, wetter AEZ $\left(D_{1 a}\right)$ recorded an early mean onset $\left(20^{\text {th }}\right.$ March $)$ and late mean retreat $\left(17^{\text {th }}\right.$ May) than the drier AEZ $\left(\mathrm{DL}_{1 b}\right)$ on which the onset and retreat dates were $26^{\text {th }}$ March and $12^{\text {th }}$ May respectively.

The length of the season and the amount of seasonal rainfall showed significant differences $(p<0.05)$ between stations. Mean length of the growing season in the Proso millet growing region was $52 \pm 8$ days $(7.4 \pm 1.1$ 
weeks). During the study period, the rainy season averaged 58 days in $\mathrm{DL}_{1 \mathrm{a}}$ and 48 days in $\mathrm{DL}_{1 b}$ AEZ. The length of the growing season decreased along the $\mathrm{DL}_{1 \mathrm{a}}$ to $\mathrm{DL}_{1 \mathrm{~b}} \mathrm{AEZ}$ (Table 3).

Proso millet requires 60-70 days to reach maturity so it will experience a dry period for 23 weeks before harvesting. Proso millet farmers prefer drier period at the latter stage of the crop because rainfall at this stage will cause seeds to shatter and plants to lodge. Higher rainfall during harvesting stage will interrupt the harvesting and postharvest handling practices, reducing both quantity and the quality of the Proso millet yield.

Thanamalwila recorded the shortest mean length of the season (Table 3). This was further complicated by the fact that onset at Thanamalwila was more variable than retreat and the higher SD for both onset and season length (Table 3 ). Therefore, timely land prep-

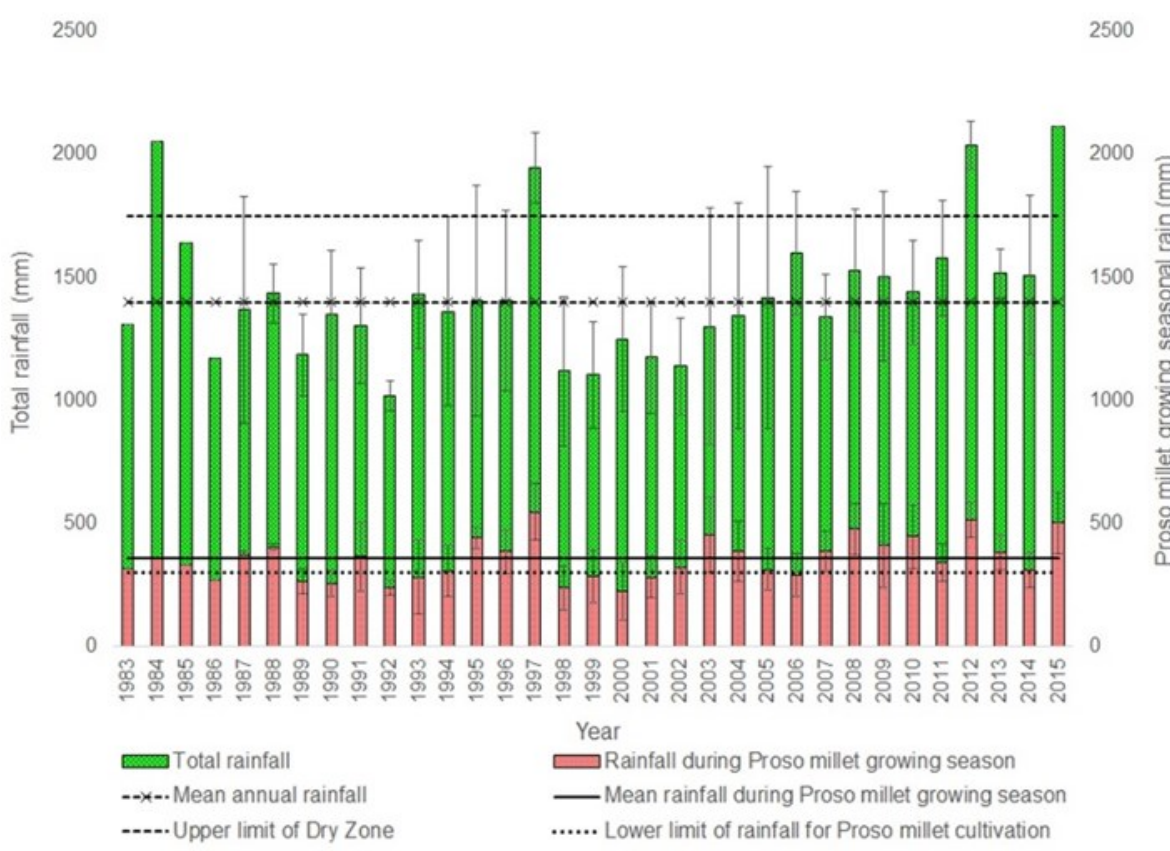

aration and seed broadcasting are more critical in Thanamalwila.

A mean of $9.4 \%$ of onset events was not identified within Yala season across the study region because it did not occur within the defined time period ( $1^{\text {st }}$ March $-1^{\text {st }}$ May). In such cases, the years were identified as years with very late onset (Table 3 ). Each station except Udawalawa showed very late onset at least once and the highest number of these events were recorded from the driest part of the study region, namely Thanamalwila (20.83 \%) and Kuda Oya (16.67 \%) (Table 3). Proso millet farmers experienced a water shortage throughout the growing season in these stations suggesting the cultivation was at risk. Except for Pelwatta, all other very late onset events belonged to Maha (the second growing season) in the region.

Mann-Kendall trend analysis revealed that there was no significant $(\mathrm{p}>0.05)$ long-term increasing or decreasing trends in the onset and retreat dates and length of the season at four stations except Thanamalwila during the period between 19832015 as onset showed a significantly decreasing trend at Thanamalwila $(\mathrm{p}<0.05)$. Due to the observed increasing trend of growing season length at Thanamalwila and Kuda Oya, the stations with the shortest growing season length (45 and 47 days respectively) have a potential of supporting crop growth in the future in terms of length.

Figure 3: Interannual variability of rainfall, averaged over the 5 sites, in the Proso millet growing regions of Sri Lanka (1983-2015). Error bars represent the standard deviation of respective means. Mean annual rainfall (above) and mean rainfall during Proso millet growing season (below) are marked in vertical lines while dash (above) and dot (below) lines represent the upper limit of Dry Zone (Punyawardena 2008) and lower limit of rainfall for Proso millet cultivation (Changmei and Dorothy 2014). 
The relationship between sowing and harvesting dates in Thanamalwila with rainfall distribution

Returning to information obtained from the farmer survey, reported sowing and harvesting frequencies are plotted along with daily rainfall amounts from Thanamalwila (the closest meteorological station - $6.5 \mathrm{~km}$ away from the centre of the survey area) and POWER in Figure 4. The results of t-test revealed that two rainfall data sets were not significantly different for $1^{\text {st }}$ March - $30^{\text {th }}$ June 2015 period $(p=0.5223)$ while significantly different $(\mathrm{p}<0.0001)$ for complete data set (POWER data available for January 1997 October 2015 period) at $95 \%$ probability level. Based on Thanamalwila data, onset and retreat of the 2015 Yala season were $3^{\text {rd }}$ April and $17^{\text {th }}$ May respectively, while for POWER data, they were $27^{\text {th }}$ March and $15^{\text {th }}$ June respectively.

Before starting the cultivation, farmers ask about rainfall events from other farmers who have fields away from the survey area or who have visited other areas. Discussions with farmers revealed that some localised rainfalls helped farmers to start the Proso millet cultivation, but they were not recorded at Thanamalwila meteorological station (Figure 4). Further, a total of $82 \%$ fields in the survey area was sown on the date of onset at Thanamawila. Therefore, the observed daily rainfall data at Thanamalwila does not in this case appear suitable for describing the farmer survey area, hence, POWER data was used for further analysis in this section.

The first sowing event was recorded on $23^{\text {rd }}$ March in the survey area. Not all the farmers waited until the onset or a rainy day to start planting the crop as $4 \%$ sow Proso millet before the rains begin (on a dry day). Rest of the fields (96\%) were sown after receiving $7 \mathrm{~mm}$ of rain. Among all, 22\% of the fields were sown before the onset of the season $\left(27^{\text {th }}\right.$ March). The highest percentage of sowing events $(26 \%)$ was on the day following onset.

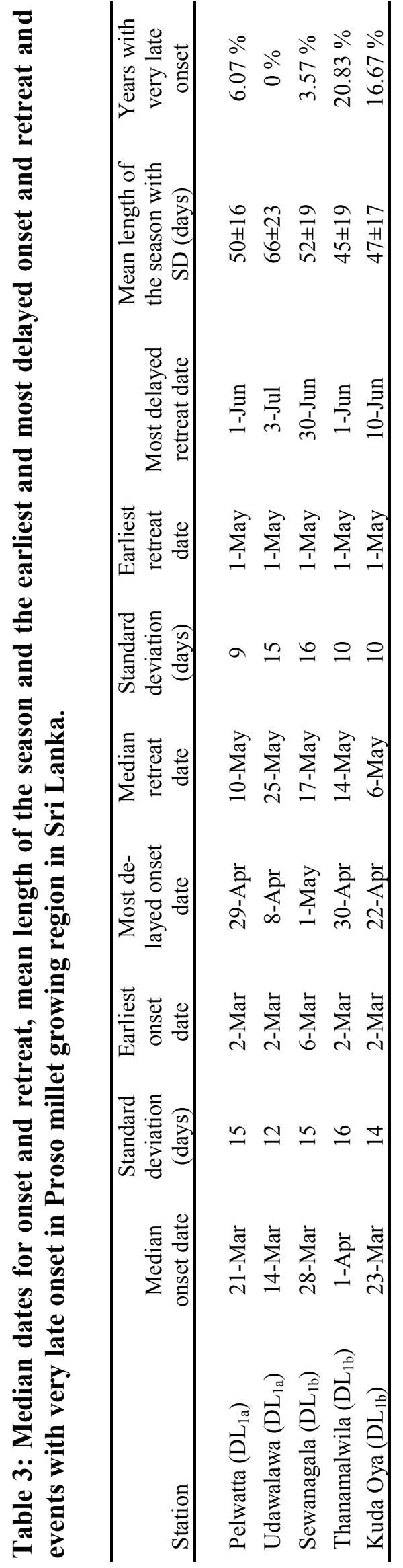


Some farmers $(12 \%)$ broadcast seeds one week after the onset. In such cases, farmers reported a failure to clear lands due to rain, lack of labour and family problems (such as funerals) led to the delay in sowing seeds.

All the farmers harvested Proso millet within the rainy season (before the retreat day). The earliest harvesting (4\%) was on $23^{\text {rd }}$ May and the remaining fields were harvested within an 8-day period from $29^{\text {th }}$ May. The length of the growing season (81 days) from POWER data for 2015 was longer than the mean length of 52 days across the region throughout the study period (1983-2015) while the length of year 2015 was 45 days. The length of growing season at Thanamalwila in 2015 was 44 days. Drier conditions during harvesting period are favourable for proper harvesting and postharvest handling as described earlier. Results of the on-farm field survey revealed that labour availability is a big issue in the area, especially for harvesting. Because farmers use family labour for land preparation and sowing. Due to lack of labour, harvesting of Proso millet can be delayed by several days. In

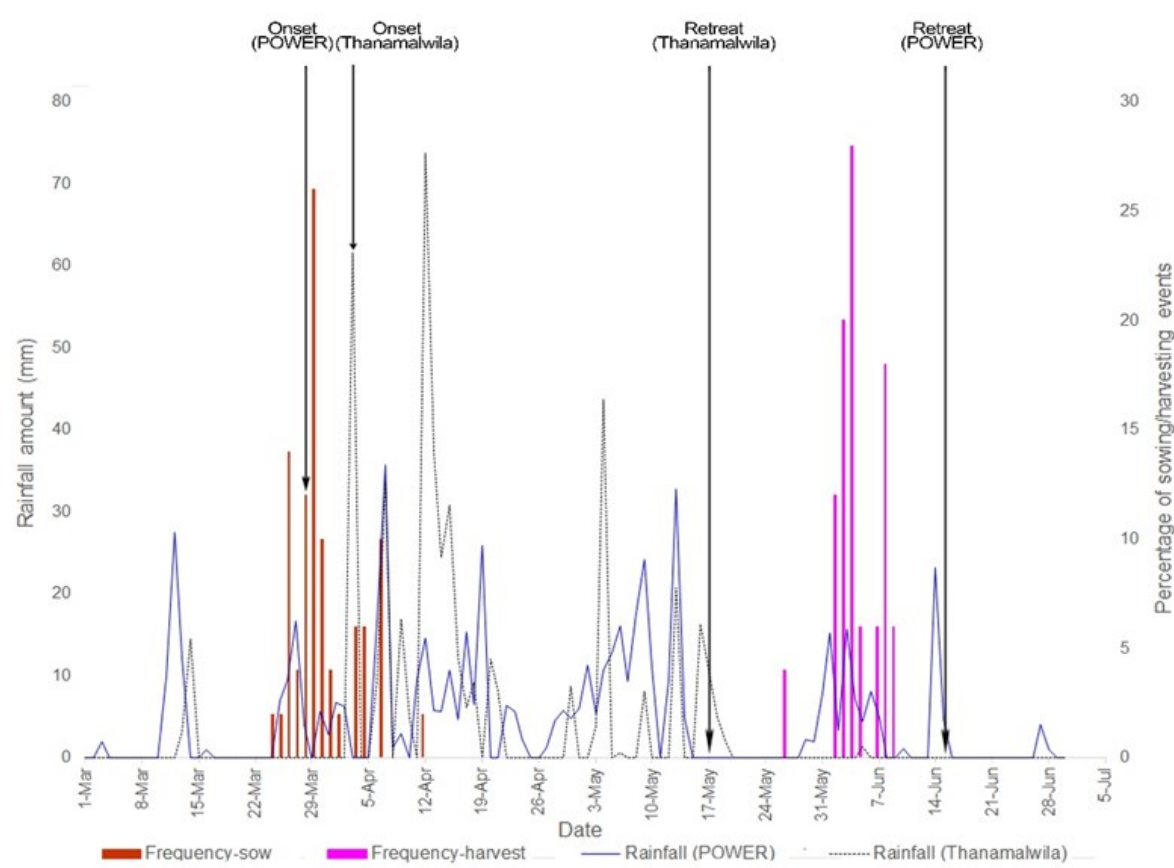

2015, the harvest was damaged due to unexpected rain, but $64 \%$ farmers harvested their fields before receiving $10 \mathrm{~mm}$ of rain, the half of the amount for the onset. In such cases, farmers delay threshing and kept the harvest in the field as a heap covered using a polyethene to protect the grain. It was often observed that some matured fields or parts of them were left without harvesting due to rain and weeds.

\section{Relationships of growing seasonal charac- teristics}

Available evidence seems to suggest that there was a considerably higher correlation $(\mathrm{r}=$ 0.7335 , significant at $p<0.05$ ) between the onset and the length of the growing season than other relationships across Proso millet growing region in Sri Lanka (Figure 5) as the relationship was significant $(\mathrm{p}<0.05)$ in all five stations. In most cases $(65.8 \%)$, the length of the season is shorter than the Proso millet lifespan (60 days) suggesting that the crop experienced drought condition during reproductive and maturity stages. The length of the growing season at Udawalawa and Sewenagala exceeded 75 days on several occasions $(47.8 \%$ and $14.8 \%$ respectively) when harvesting and postharvest handling of Proso millet could be affected by rainfall as happened during 2015 at Bodagama, Sri Lanka (Figure 4).

Other key information that would assist in agricultural planning is the relationship between onset and the amount of rainfall during a season. However, a poor correlation $(\mathrm{r}=-0.4799)$ was observed between the onset and seasonal rainfall in Proso millet growing region in

Figure 4: Farmers' sowing and harvesting dates of Proso millet and distribution of rainfall (POWER-straight blue line and Thanamalwila-dot line) in Bodagama, Sri Lanka during 2015 Yala season 
LCDZ, Sri Lanka.

\section{Dry spells during the growing season}

The probability of 7-day dry spells in a period of 30 days during the Proso millet growing season followed a similar pattern in all the stations (Figure 5) but they were significantly $(\mathrm{p}<0.05)$ different. The lowest probability of 7-day dry spell in Thanamalwila was from $22^{\text {nd }}$ March to $29^{\text {th }}$ March, during the data period. Interestingly, the on-farm field survey results revealed that mean and median Proso millet sowing dates for 2015 were $29^{\text {th }}$ March and $28^{\text {th }}$ March respectively. It was recorded that Proso millet farmers in the area select the day with the lowest probability of potentially damaging dry spell to sow seeds that will reduce seed desiccation and increase plant emergence. It comes from their experience and none of the farmers check the water availability by testing soil moisture in the field in to a certain depth.

Proso millet fields near Thanamalwila and Kuda Oya experience a higher probability ( $98 \%$ and $97 \%$ respectively) of 7-day dry

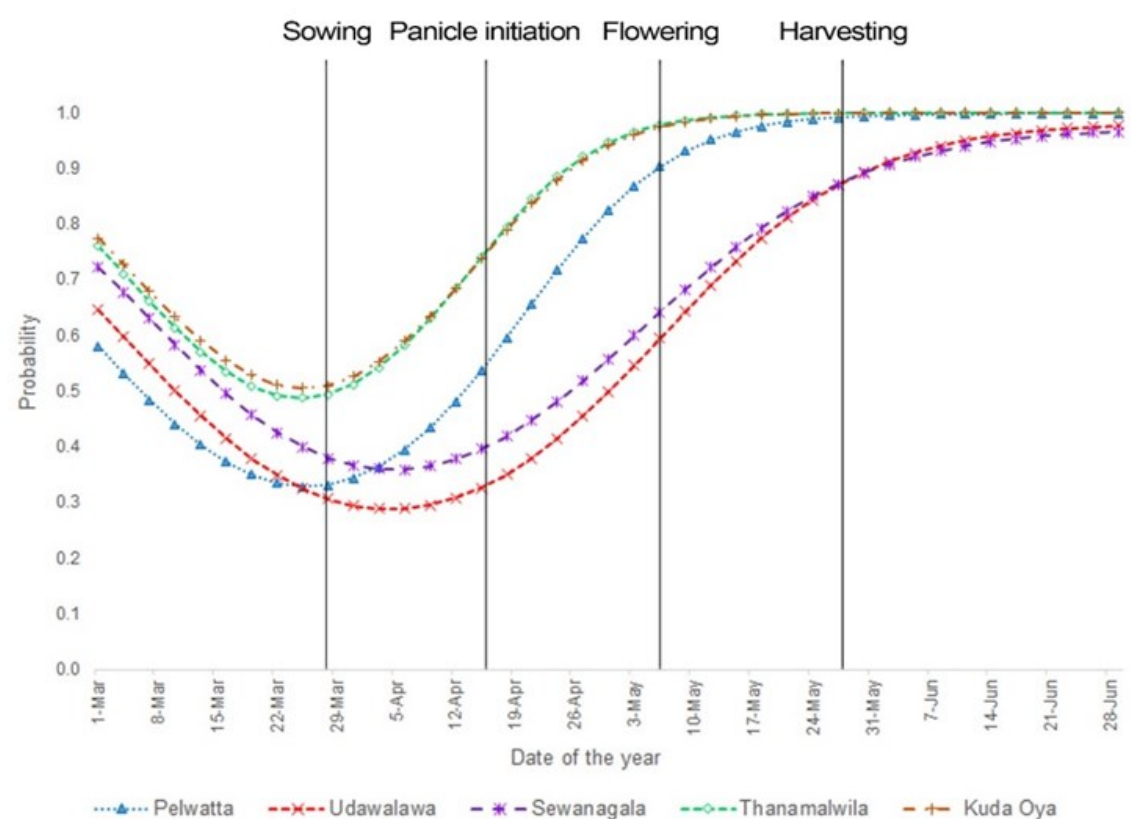

spells at flowering stage, but the probability was comparatively lower in other stations. The risk of 7-day dry spells was lower during the initial crop growth phases but increased with the age. Proso millet plants at reproductive and ripening stages are more vulnerable to long-term dry spells.

Both seeds and seedlings of Proso millet can be damaged due to heavy rain and drought during the initial phases of the crop, causing uneven crop stand across the field or permanent loss of the crop. Proso millets fields are never re-sown to fill the gaps and farmers maintain and harvest the remaining parts of the field. The strategy used by farmers to protect against unexpected damages was to maintain a high plant density, as described in earlier. The amount and favourable distribution of rainfall during Proso millet growing period are key factors for a successful cultivation.

Rainfall amount and distribution determines the lifestyle of subsistence farmers in agricultural areas in Sri Lanka. All the farming activities in the Proso millet growing area were found to be heavily depended on the amount and the distribution of rainfall which agrees with the findings of Gunarathna et al., (2004).

Previous work on growing seasonal characteristics of the LCDZ in the southern plains of Sri Lanka was almost nonexistence, therefore this analysis can be used to make recommendations for farmers in those areas. Previous studies of Punyawadena (2002) recorded that onset and retreat of Yala season in the North Cen-

Figure 5: The probability of 7 days dry spells in a period of 30 days centred on a particular day during the Proso millet growing season in Low Country Dry Zone Sri Lanka for 19832015 period. All the dates marked in this figure are based on information from the farmer survey. 
tral Dry Zone that belongs to the $\mathrm{DL}_{1 \mathrm{~b}}$ AEZ were in late March $\left(13^{\text {th }}\right.$ week) and in late April (between $18^{\text {th }}-19^{\text {th }}$ week) respectively. Observed mean onset $\left(12^{\text {th }}\right.$ week) and retreat $\left(20^{\text {th }}\right.$ week) in the Proso millet growing region were different to the findings of Punyawadena (2002) by one week. The mean of 7.4 -week length of growing season across Proso millet growing area was much higher than the 5-week period reported by Punyawadena (2002).

Sri Lankan climate is divided into two cultivation seasons by different timescales as identified in different studies (Zubair 2002; De Silva et al 2007; Chithranayana and Punyawardena 2008; Sonnadara 2015). However, we found the actual growing season that supports crop cultivation is far below the hypothetical growing season reported in most studies. Rainfall retreat 11-15 weeks before the generally accepted end to growing season (Yala) defined in the literature. Southwest Monsoon is not clearly observed in the area (Punyawardena 2008) and creates water scarcity during the latter part of Yala that limits the options for crop cultivation in the Proso millet growing region in June onward.

Since the first rain event is not always followed by the onset of the rainy season in the area (Figure 4), dry spells could occur during early stages of the crop growth. Therefore, it is worth to distinguish the dry spell to avoid the false onset when identifying the best sowing date. Marteau et al., (2011) investigated the relationship of rainfall onset and farmers' sowing strategy for Pearl millet cultivation in Southwest Niger, finding that most farmers waited for the first rain event before sowing whereas a few of them sow seeds before the rains, i.e. when the soil is dry. This is called 'dry seeding' and allowed farmers to get more arable lands sown at the time of onset and reduce time-consuming land preparation after the first useful rain. On the other hand, this technique has a higher possibility of having poor plant establishment due to damage caused by insects, birds, and seed desiccation (Liboon et al., 2001).

Some other Proso millet farmers avoid seeding at the onset of the rainy season to protect seeds from heavy rain. The inability to sow in a rainy day, with farmers reporting this could be due to delay in land preparation, or social and religious activities, lead to dry seeding of Proso millet. But, the dry seeding is not a farming technique followed by Proso millet farmers in Sri Lanka as an adaptation strategy to rainfall variability and to the labour shortage, such as commonly practised in Niger (Marteau et al., 2011). The date of seed broadcasting varied within a couple of weeks in the same area, but discussions with farmers and survey results revealed that the sowing date solely depends on rainfall. Therefore, any changes in the onset of the rainy season will affect the Proso millet cultivation in the area.

Different crop growth stages are sensitive to water availability in different ways. In Proso millet, the greatest reduction of water use efficiency $(32.0 \%$ to $36.4 \%)$ was reported during the ear emergence stage (Seghatoleslami et al., 2008). Further, these authors reported that floret death and lowering of seed weight that reduces the harvest index are the major impacts caused by the drought stress at ear emergence stage. Avoidance of moisture stress at ear emergence and flowering by the possible shift of the sowing date to a later date is limited by variation in the onset date because false onset can damage the crop in early stages. The higher probability of long term dry spells during the reproductive stage (Figure 5) that limits water availability in the most sensitive growth stage can be the reason for the lower yield recorded in yield analysis.

Delayed onset of rainfall is one of the major climate related agricultural issues that responsible for abnormal cropping calendar, crop failure and yield reduction in Intermediate Zone (IZ), Sri Lanka (Esham and Garforth, 2013). Change in planting dates, changing 
crop varieties and crop rotation are the most prevalent adaptation strategies practised in Mid Country Sri Lanka to bypass the critical crop growth stages from overlapping dry periods (Esham and Garforth, 2013). The comparatively shorter length of the growing season than that which occurs in the Wet and IZ, low water availability and high variability of rainfall in the area (Punyawardena, 2002) limit the usage of these management practices in Proso millet growing region in Sri Lanka. Changing planting date is a no cost adaptation strategy that can be implemented at the farm level, but large shifts would affect the management of other crops grown during rest of the year (Mall et al., 2006). Proso millet cultivation in year 2015 experienced a higher probability of 7 -day dry spells (98\% at Thanamalwila) during the flowering stage (Figure 5). Delayed planting of Proso millet makes the plants more susceptible for dry spells from the vegetative growth stages. Furthermore, changes in cropping sequence and land use can be used as an alternative adaptation option under the changing rainfall pattern. In some regions, low availability of land areas limits the possibility of shifting Proso millet cropping fields, as it is most common in the Chena farming systems.

Rainwater harvesting, improvement of soil, water and nutrient holding capacity and soil conservation were not practised in Proso millet fields. Due to the short rainy season in some areas, it is important to invest in soil, water and nutrient management technologies for Proso millet cropping systems. But most of the Proso millet farmers are practising shifting cultivation inside the small forest areas and therefore, it limits the possibilities of introducing new technology.

It is important to identify the vulnerability to climate change in the region and suitable adaptation strategies. Research should be encouraged to identify and develop crop varieties that can sustain good yields under the changing climate conditions. Further, research attention is required on seed/plant densities, soil improvement and management practices that increase the yield. Modern agricultural technologies should be introduced to low input agricultural systems in the region.

\section{CONCLUSION}

The selection of crops and crop management practices in the Proso millet growing area in Sri Lanka coincided with the distribution of rainfall. The mean rainfall during the Proso millet growing season throughout the study period $(361 \mathrm{~mm})$ is higher than the lower limit of rainfall $(300 \mathrm{~mm})$ where Proso millet gives a satisfactory yield, based on the literature. But, the yields reported by farmers (ranged from 0.470 to $1.956 \mathrm{t} \mathrm{ha}^{-1}$ ) are far below the potential value $\left(4 \mathrm{t} \mathrm{ha}^{-1}\right)$. Date of onset was not significantly different among stations and can be successfully used to predict the length of the season in Proso millet growing region in Sri Lanka. Implementation of soil moisture conservation and water management practices are critical for a successful Proso millet cultivation in Low Country Dry Zone Sri Lanka.

\section{ACKNOWLEDGEMENT}

Authors thank to Sugarcane Research Institute (SRI), Department of Irrigation Sri Lanka and Lanka Sugar Company Ltd. for providing observed daily precipitation data. We are also grateful to the financial supports of The University Gants Commission Sri Lanka (UGC), Crops For the Future, Malaysia (CFF), University of Nottingham Malaysia Campus (UNMC) and Sabaragamuwa University of Sri Lanka (SUSL).

\section{REFERENCES}

Aviad Y, Kutiel H and Lavee H 2004 Analysis of beginning, end and length of the rainy season along a Mediterranean arid climate transect for geomorphic purposes. J. Arid Environ. 59:189-204.

Changmei S and Dorothy J 2014 Millet-the frugal grain. Int. J. Sci. Res. Rev. 3:75-90.

Chithranayana RD and Punyawardena BVR 2008 Identification of drought prone agro- 
ecological regions in Sri Lanka. J. Natl. Sci. Found Sri Lanka. 36(2):117-123.

De Silva CS, Weatherhead EB, Knox JW and Rodriguez-Diaz JA 2007 Predicting the impacts of climate change. A case study of paddy irrigation water requirements in Sri Lanka. Agric. Water Manag. 93:19-29.

Esham M and Garforth C 2013 Agricultural adaptation to climate change: Insights from a farming community in Sri Lanka. Mitig. Adapt. Strategies Glob. Change. 18:535549.

Gunarathna MHJP, Navaratne $\mathrm{M}$ and Weerasinghe KDN 2004 Effect of rainfall on cropping pattern of farmers in Hambantota District. pp 49-54. In: Second Academic Sessions. Sri Lanka: Univ. Ruhuna, Sri Lanka.

IPCC. 2014: Summary for policymakers. In: Climate Change 2014: Impacts, adaptation, and vulnerability. Part A: Global and sectoral aspects. Contribution of working group II to the Fifth Assessment Report of the Intergovernmental Panel on Climate Change. Field CB, Barros VR, Dokken DJ, Mach KL, Mastrandrea MD, Bilir TE, Chatterjee M, Ebi KL, Estrada YO, Genova $\mathrm{RC}$ and et al (eds). World Meteorological Organisation, Switzerland. pp. 22.

Kendall MG 1975 Rank Correlation Methods. $4^{\text {th }}$ ed. Charles Griffin, London.

Liboon SP, Abrogena NQ, Aguinaldo A, Castro R and Sebastian LS 2001 Modified dryseeding with zero tillage $\&$ straw mulching: A new technology package for rain fed rice. Philipp. J. Crop Sci. 26(2):5-13.

Mann HB 1945 Non parametric test against trend. Econometrica. 13:245-259.

Marteau R, Sultan B, Moron V, Alhassane A, Baron C and Traore SB 2011 The onset of the rainy season and farmers' sowing strategy for Pearl millet cultivation in Southwest Niger. Agric. For. Meteorol. 151(10):13561369.

Mavi HS and Tupper GJ 2004 Agrometeorology: Principles and Application of Climate Studies in Agriculture, Food Products Press, New York. pp. 70-71.

Mupangwa W, Walker S and Twomlow S 2011 Start, end and dry spells of the growing season in semi-arid southern Zimbabwe. J. Arid Environ. 75:1097-1104.
Omotosho JB, Balogun AA and Ogunjobi K 2000 Predicting monthly and seasonal rainfall, onset and cessation of the rainy season in West Africa using only surface data. Int. J. Climatol. 20:865-880.

Punyawardena BVR 2002 Identification of the potential of growing seasons by the onset of seasonal rains: A Study in the $\mathrm{DL}_{1}$ region of the North Central Dry Zone. J. Natl. Sci. Found Sri Lanka. 30(1\&2):13-21.

Punyawardena BVR 2008 Precipitation of Sri Lanka and agro-ecological regions. Sri Lanka: Agriculture Press.

Ravi SB, Swain S, Sengotuvel D and Parida NR 2010 Promoting nutritious millets for enhancing income and improved nutrition: A case study from Tamil Nadu and Orissa. pp. 19-46. In: Mal B, Padulosi S and Ravi SB (eds.) Minor millets in South Asia. India: Biodiversity International, Maccarese, Rome, Italy and the M.S. Swaminathan Research Foundation.

Seghatoleslami MJ, Kafi M and Majidi E 2008 Effect of deficit irrigation on yield, WUE and some morphological and phenological traits of three millet species. Pak. J. Bot. 40 (4):1555-1560.

Stern R, Knock J, Rijks D and Dale I 2003 INSTAT Climatic Guide: The University of Reading; [cited 2015 Sep 25]. Available from http://www.reading.ac.uk/ssc/software/ instat/climatic.pdf

Suppiah R 1996 Spatial and temporal variations in the relationships between the Southern Oscillation phenomenon and the rainfall of Sri Lanka. Int. J. Climatol. 16:1391-1407.

Swaminaidu N, Ghosh SK and Mallikarjuna K 2015 Millets: The Miracle Grains. Int. J. Pharm. Bio Sci. 6(4):440-446.

Zhang T, Chandler WS, Hoell JM, Westberg D, Whitlock CH and Stackhouse PW 2007 A Global Perspective on Renewable Energy Resources: NASA's Prediction of Worldwide Energy Resources (Power) Project. In: Proceedings of ISES World Congress. 9(IV): 2636-3264.

Zubair L 2002 El Niño-Southern Oscillation influences on rice production in Sri Lanka. Int. J. Climatol. 22:249-260. 